that during long-term therapy the plasma digoxin concentration reflects the tissue concentration because of a fairly predictable plasma:tissue distribution ratio. All the patients with digoxin toxicity reported here had been previously digitalized and intoxication occurred during the process of chronic therapy as a result of the slow accumulation of digoxin. In this clinical context it is possible to cautiously plan a therapeutic approach to the problem on the basis of the results obtained.

If an adult patient has been digitalized with digoxin and has been taking digoxin orally for more than three days, and presents with symptoms or signs suggestive of digoxin toxicity and the plasma potassium is not less than $3.5 \mathrm{mEq} / 1$., then:

(1) If the plasma digoxin concentration is less than $4 \mathrm{~m} \mu \mathrm{g} . / \mathrm{ml}$, digoxin intoxication is very unlikely.

(2) If the plasma digoxin concentration lies between 4 and 5 $\mathrm{m} \mu \mathrm{g} . / \mathrm{ml}$., then digoxin intoxication is very likely and digoxin therapy should be temporarily stopped and restarted at a lower dose. Certainly increasing the dose of digoxin would be contraindicated. If in this situation emergency therapeutic measures were indicated, a fairly safe assumption of digoxin intoxication could be made and appropriate measures instituted.

(3) If the plasma digoxin concentration is greater than $5 \mathrm{~m} \mu \mathrm{g} . /$ ml., then a definite diagnosis of digoxin toxicity could be made.

The nine patients whose plasma digoxin concentrations are depicted in Fig. 2 as toxic have been handled according to these criteria with impressive clinical improvement.

In two of the illustrative cases (Nos. 1 and 2) sequential E.C.G. tracings are shown (Figs. 3 and 4) and though in these cases there are other possible causes of increasing S-T segment sagging these changes progressed as the plasma digoxin concentrations rose and the patients became intoxicated.

The measurement of plasma digoxin concentration would seem to offer a rational approach to the diagnostic problem of digoxin intoxication and helps in distinguishing those cases in which the presenting symptoms and signs might be due either to the intrinsic heart disease or to digoxin toxicity. The alternatives to a method such as that described here are double isotope derivative dilution assays, such as that described by Lukas and Peterson (1966) for digitoxin, and radioimmunoassay techniques as described by Butler and Chen (1967) for digoxin and by Oliver et al. (1968) for digitoxin. Double isotope derivative dilution assays take far too long to be of much use in a clinical situation, and the radioimmunoassay techniques seem to offer little advantage over the procedure described and are at present too complex to be of widespread applicability.

We are grateful to the physicians of St. Mary's Hospital who allowed us to study patients under their care, and also to the Endowment Fund of St. Mary's Hospital and Pfizer Limited for financial support.

\section{REFERENCES}

Butler, V. P., jun., and Chen, J. P. (1967). Proc. nat. Acad. Sci., 57, 71. Glynn, I. M. (1957). f. Physiol. (Lond.), 136, 148.

Love, W. D., and Burch, G. E. (1953). F. Lab. clin. Med., 41, 351.

Love, W. D., and Burch, G. E. (195ion, $31,228$.
Lowentein, J. M. (1965). Circulation. Corrill, E. M. (1966). F. Lab. clin. Med., 67, 1048.

Lukas, D. S., and Peterson, R. E. (1966). 7. clin. Invest., 45, 782.

Lyon, A. F., and DeGraff, A. C. (1967). Amer. Heart F., 73, 134.

Oliver, G. C.., Parker, B. M., Brasfield, D. L., and Parker, C. W. (1968). 尹. clin. Invest., 47, 1035 .

\title{
Cellular Viraemia in Babies Infected with Rubella Virus before Birth
}

\author{
IAN JACK,* M.SC. ; JOCELYN GRUTZNER,*† B.SC.
}

Brit. med. f., 1969, 1, 289-292

\begin{abstract}
Cummary : Chronic viraemia has been detected in $\mathbf{1 0}$ $\$$ out of 12 rubella syndrome babies at periods ranging from 1 to 196 days. The virus was found to be associated with leucocytes, and it is assumed that removal of neutralizing antibody is the most likely explanation for the high success rate in detecting viraemia. The findings are discussed in relation to diagnosis by virus isolation, to pathogenesis, and to the possible significance in explaining the failure of the foetus to develop a tolerance to rubella virus. Several published reports of viraemia in the acute exanthematous disease are contrasted with the less frequent reports of viraemia in the chronic disease of early postnatal life.
\end{abstract}

\section{Introduction}

The chronic excretion of rubella virus for the first two to three years after intrauterine infection is now well recognized (Phillips et al., 1965 ; Dudgeon, 1967). However, despite recovery of virus from various tissues and excretions, isolation from blood has been reported only rarely.

\footnotetext{
- Sporting Globe-3DB Research Laboratories, Department of Pathology, Royal Children's Hospital, Parkville, 3052, Australia. t Present address: Los Angeles County General Hospital, California,
U.S.A.

This paper describes rubella virus isolation from the peripheral blood of 10 out of 12 congenitally infected babies tested at ages ranging from 1 to 331 days. The demonstration of cellular viraemia is important not only as an adjunct to diagnosis, as it was in three patients, but also in relation to an understanding of the pathogenesis and the immunological aspects of the congenital rubella syndrome.

\section{Materials and Methods}

Patients.-Oniy 12 of the 33 virus-proved congenital rubella babies seen at this hospital in the past three years were studied for evidence of viraemia. They were selected in a random manner without regard to age or to degree of severity of their illnesses. The clinical course varied from patient to patient, but as these details are beyond the scope of this report case histories are not presented.

Virus Isolation.-The specimens examined varied with each patient, and though rubella virus isolation was attempted, usually from throat swabs, urines, and unclotted blood conjunctival swabs, lens aspirates and necropsy specimens were also tested. Cell cultures used for virus isolation included continuous rabbit kidney cell line (RK13, Glaxo; not freed of mycoplasma contaminants) and primary or secondary cultures of cynomolgus monkey kidney epithelium (MK). In the former 
cells a characteristic cytopathic effect was detected in 5 to 10 days, and in the $M K$ the presence of rubella virus was inferred from the finding that a challenge inoculum of echovirus 11 (100 $\mathrm{TCD}_{50}$ given at 14 days) failed to produce a cytopathic effect in two to three days. Occasionally a second passage to MK was required before interference was detected. The identity of the interfering agent in $M K$ or of the cytopathic agent in RK13 cells was established by specific neutralization with a rabbit serum prepared against a local strain of rubella virus.

Preparation of Blood Specimens.-Blood for virus isolation (usually $2.5 \mathrm{ml}$.) was collected in sterile containers, ethylenediaminetetracetate or preservative-free heparin (preferably the former) being used as anticoagulant. After allowing the erythrocytes to settle in narrow-bore tubes for 30 to 60 minutes the leucocytes were recovered from the supernatant plasma by centrifuging at $600 \mathrm{~g}$ for two minutes, and were washed once with approximately $2 \mathrm{ml}$. of $0.25 \%$ gelatin saline buffered to $p \mathrm{H} \mathrm{7 \cdot 4}$. The washed leucocytes, resuspended in a small volume of fresh saline, were seeded in duplicate to roller tube cultures of $\mathrm{RK} 13, \mathrm{MK}$, and occasionally to human diploid fibroblast cultures. In some instances cell-free plasma was inoculated to cultures at the same time, or after short-term storage at $-70^{\circ} \mathrm{C}$. In all instances cultures were not given a change of maintenance medium until cells had been in contact with the monolayer cells for at least 48 hours.

\section{Results}

Viraemia was detected in 10 of the 12 babies studied. Table I lists the ages at which viraemia was demonstrated in these 10 , and the ages at repeat examination of four of the babies. It also shows that the blood specimens of seven of the babies were examined by additional or alternative methods, three being inoculated without washing the leucocytes free of antibody. On four occasions sufficient blood was available to allow the preparation of primary cultures of leucocytes, which were cultured for thiee to nine days before transfer to monolayer cultures of RK13 or MK cells. Three of these four primary cultures utilized purified preparations of lymphocytes as described by Simons and Jack (1968). Table I also lists the sources and times of virus excretion at other sites.

Except for second specimens obtained from four babies no attempt was made to determine the duration of viraemia in individual patients. Within this context viraemia was detected at least once at 1 to 196 days of age in eight patients and twice in the other two at 14 and 24 days and at 2 and 58 days respectively.

Of the two patients whose plasma was tested at the time of proved cellular viraemia only one was found positive. As his serum was found to contain haemagglutinin-inhibiting antibody and as he was not hypogammaglobulinaemic (unpublished) it is possible that this virus came from residual leucocytes present in the lightly centrifuged plasma.

One of the two patients without demonstrable cellular viraemia (Case 7) was found to have virus in his bone marrow when tested 56 days earlier, and another (Case 5), though viraemic at 46 days of age, was still bone-marrow positive at 331 days, at which stage the peripheral cellular viraemia was no longer demonstrable.

In three patients the recovery of rubella virus from the blood was diagnostically important as it had not been isolated from other specimens. Necropsy tissues of Case 1 taken at the same time as blood were negative. The throat swab of Case 10 was negative at seven days of age, and this and urine were also negative at 117 days, though viraemia was detected at this latter age. This patient's lens tissue taken at 280 days of age was also found to contain rubella virus. In Case 12, an apparently normal infant of a mother who experienced clinical rubella at 16 weeks' gestation, virus was not recovered from the throat at 2 days of age, but his leucocytes were positive then and again at 58 days, when he still appeared free of signs of congenital rubella syndrome.

No precise estimate of the relative value of RK13 cells and cynomolgus MK tissue could be made from this series of 12 patients or the other 21 congenital rubella patients whose blood was not tested, but we found that RK13 cells were slightly more useful because results were obtained earlier. Occasionally, however, MK isolation succeeded where RK13 cells failed, and so we continue to use both systems even though this dissipates the infected leucocytes to extra cell cultures.

\section{Discussion}

The finding of chronic viraemia in congenital rubella patients has both practical and theoretical implications. The recognition of cellular viraemia in addition to plasma viraemia in several virus diseases of man and animals (reviewed by Mims, 1964) has allowed laboratory workers a wider choice of specimens from which to attempt isolation of viruses for diagnostic purposes. Indeed, in this rubella series virus was recovered from the leucocytes of three patients though other specimens taken at the same age were negative. The recognition of longterm cellular localization of rubella viruses may offer an explanation for the failure of most of these babies to become tolerant to rubella virus and may also provide an explanation for the coexistence of chronic infection and specific neutralizing antibody.

In human diseases the advantage of using leucocytes in the search for viraemia was first shown in the case of measles virus infections. Gresser and Chany (1963) showed that whereas viraemia was demonstrable in serum or whole blood in the in-

TABLE I.-Isolation of Rubella Virus from Blood and Other Tissues of Congenital Rubella Babies

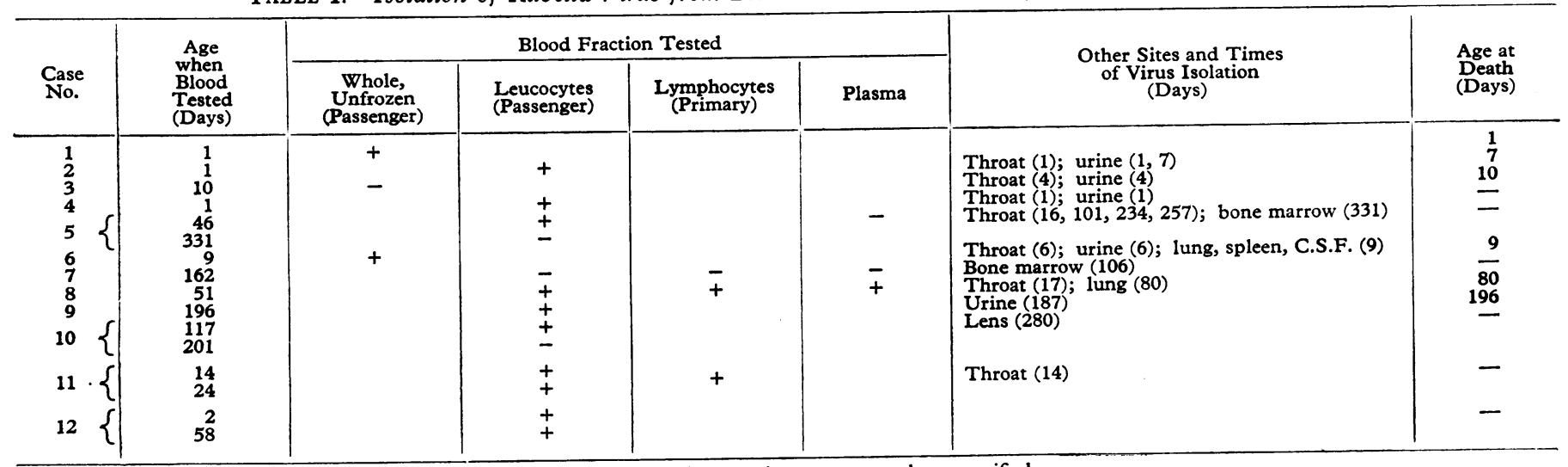


cubation period before the appearance of the rash it was less readily detected in these specimens 24 hours after the rash had appeared, though washed leucocytes were positive. They considered that the use of fresh or lysed whole blood collected at this later stage was unsatisfactory because neutralizing antibody was already present in inhibitory concentrations in the serum. It is also possible that the viable but infected leucocytes held as passenger cultures in appropriate host cell cultures allow an intraleucocytic enrichment of an initially low concentration of virus before generalized infection of the host cell monolayer begins. In another human virus infection the use of washed leucocytes taken at a late stage of the illness has permitted a clearer interpretation of the role of cytomegalovirus infection in some cases of post-transfusion mononucleosis syndrome (Foster and Jack, 1968 ; Lang et al., 1968). In this system an additional reason for failure to isolate viruses from human blood became apparent-namely, that slow-growing viruses present in an immature state might be destroyed by the routine disruptive techniques used by virologists in getting viruses out of infected cells.

Several reports of viraemia in classical rubella are available, and a non-exhaustive analysis of these is presented in the first part of Table II. In the classical disease it seems that those specimens of whole blood or of serum taken before the appearance of the rash have been the most useful, and it is interesting to note the finding of Horstmann et al. (1965) that serum taken on the day of the rash was more often found to contain detectable virus if diluted $1 / 500$ before inoculation to cell cultures than if used undiluted. Reports from laboratories engaged in human volunteer studies (Green et al., 1965 ; Schiff et al., 1965) indicate that a plasma viraemia exists for the last seven days of the incubation period and ceases with the appearance of the rash, at which stage neutralizing antibody is also detectable for the first time (Sever et al., 1966 ; Meyer and Parkman, 1967).

Reports of attempted laboratory demonstration of viraemia in congenital rubella infections are scanty, possibly reflecting a lack of interest in going beyond simpler examinations such as urines and throat swabs for ordinary diagnosis, or possibly reflecting the usual rcticence in publishing negative results. Five reports are listed in the second part of Table II. Phillips et al. (1965) in reporting viraemia in only 2 out of 45 babies suggested that any viraemia was limited to the first weeks of life, but Plotkin et al. (1966) reported viraemia (? plasma) at the age of 5 months in a hypogammaglobulinaemic patient who was deficient in rubella-neutralizing antibody.

Having demonstrated that cellular viraemia does exist postnatally in babies infected before birth it is perhaps not so surprising that the viraemia should prove to persist for long periods. The chronicity of rubella virus excretion at other sites is now well recognized (Phillips et al., 1965), though the exact time relationship for recovering it from particular sites has yet to be placed on a firm basis. Cooper and Krugman (1966) found that an initial high success rate in isolating the virus fell with increasing age, and that whereas $60-80 \%$ of tests made on various specimens at birth were positive, this fell to $30 \%$ at the age of 6 months and to $7 \%$ by 10 months of age. Other workers have attempted to establish a ranking list for the practicability of using various specimens for virus isolation in patients not seen until several months of age. Plotkin et al. (1967) ranked lens $47 \%$, throat $9 \%$, and cerebrospinal fluid $5 \%$ at 12 months of age.

TABLE II.-Methods Used and Results Obtained by Various Authors for Viraemia in Rubella Infections

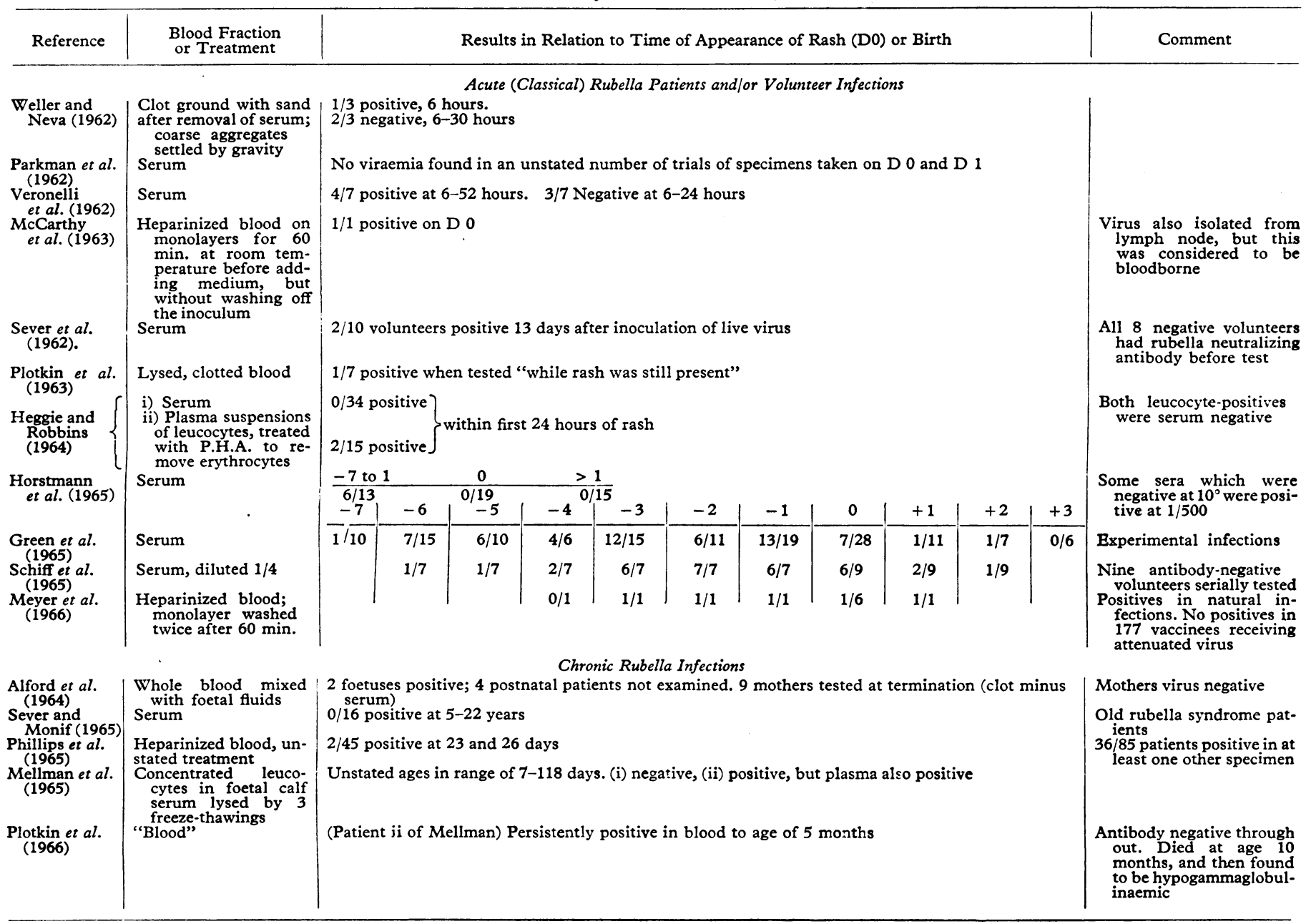


The findings of chronic cellular viraemia in the 10 cases described in this paper derive from studies made in our routine diagnostic service without preferential treatments such as longer incubation of cultures or blind passaging of cultures, etc. The finding that viraemia is of longer duration than hitherto accepted is likely to represent an advance in technique rather than an attribute of a peculiarly Australian strain of rubella virus. The 12 patients were chosen in an apparently random fashion, but it was found that they suffered a higher mortality rate $(6 / 12)$ than the remaining proved congenital rubella patients whose leucocytes were not cultured $(4 / 21)$. Although :his difference is not statistically significant $\left(\chi^{2}=3.6,0.1>\mathrm{P}>\right.$ $0.05)$, it would seem that further studies are needed to clarify the relation between duration of viraemia and severity of the postnatal illness. Additionally it seems relevant to examine patients for viraemia in relation to the degree of haematological efrects of the continuing postnatal illness. Zinkham et al. (1967) and Rausen et al. (1967) reported varying degrees of haematological involvement and each group isolated virus from bone marrow specimens. It remains to be determined whether find$i_{i}$ gs of peripheral cellular viraemia in the cases described in this paper represent solely persistence of virus in long-lived peripheral leucocytes or localized infection at bone marrow production centres.

To revert to the theoretical implications of these findings of subacute or chronic viraemia in rubella syndrome babies, one wonders what role an intracellular location of virus during foetal life would play in the failure of the development of immune tolerance. Dudgeon et al. (1964) and Dudgeon (1967) reported that $95 \%$ of babies with congenital rubella virus infection are born with significant levels of their own immunoglobulins (IgM) with specific neutralizing activity. Simons (1969) discussed the proposal of Dent et al. (1968) that there must be a deficiency of cellular immune competence underlying the failure of the body to rid itself of infectious virus. In his view there is no need to postulate an impairment of lymphoid system function to explain the postnatal persistence of virus. Rubella virus could be expected to survive for as long as the life of infected cells and their descendants irrespective of the state of development of the immune system.

A second major problem concerns the failure of the foetus to become tolerant to rubella virus. Our findings of postnatal cellular viraemia lead us to suspect that cellular sequestration of the virus in utero may be a critical mechanism underlying this latter failure, but if this is so it would be necessary to postulate a time difference in the completeness of the sequestration. Early in foetal life most rubella virus may be effectively excluded from the immature immune system. Concurrently with, but independently of, the maturation of this system infection of leucocytes and other cells would lead to an increased pool of antigen, some of which by leakage from viable cells or after cell death would give rise to immunizing levels of soluble antigens. Despite the difficulties involved, the examination of therapeutically and spontaneously aborted foetuses for both cellular and plasma viraemias at various stages in gestation would appear essential in order to clarify the role of cellular sequestration of virus in the immune response seen in the rubella syndrome.

We are indebted to the members of the clinical staff of this hospital for providing specimens from the patients under their care, and for clinical records. Mr. E. C. Uren provided valuable assistance in isolating virus from the last three patients, and Dr. D. M. Danks advised on statistics and reviewed the manuscript. We are also pleased to thank Dr. M. J. Simons for column purification of lymphocytes from some patients and for stimulating discussions concerning immunological aspects of lymphocyte viraemia in congenital infections.

\section{REFERENCES}

Alford, C. A., jun., Neva, F. A., and Weller, T. H. (1964). New Engl. f. Med., 271, 1275 .

Cooper, L. Z, and Krugman, S. (1966). Pediatrics, 37, 335.

Dent, P. B., Olson, G. B., Good, R. A., Rawls, W. E., South, M. A., and Melnick, J. L. (1968). Lancet, 1, 291.

Dudgeon, J. A. (1967). Arch. Dis. Childh., 42, 110.

Dudgeon, J. A., Butler, N. R., and Plotkin, S. A. (1964). Brit. med. F., 2, 155 .

Foster, K. M. and Jack, I. (1968). Aust. Ann. Med., 17, 135.

Green, R. H., Balsamo, M. R., Giles, J. P., Krugman, S., and Mirick, G. S. (1965). Amer. F. Dis. Child., 110, 348.

Gresser, I., and Chany, C. (1963). Proc. Soc. exp. Biol. (N.Y.), 113, 695

Heggie, A. D., and Robbins, F. C. (1964). New Engl. F. Med., 271, 231.

Horstmann, D. M., Riordan, J. T., Ohtawara, M., and Niederman, J. C. (1965). Arch. ges. Virusforsch., 16, 483.

Lang, D. J., Scolnick, E. M., and Willerson, J. T. (1968). New Engl. 7. Med., 278, 1147.

McCarthy, K., Taylor-Robinson, C. H., and Pillinger, S. E. (1963). Lancet, 2, 593.

Mellman, W. J., Plotkin, S. A., Moorhead, P. S., and Hartnett, E. M. (1965). Amer. F. Dis. Child., 110, 473 .

Meyer, H. M., and Parkman, P. D. (1967). Amer. F. med. Sci., 253, 364.

Meyer, H. M., jun., Parkman, P. D., and Panos, T. C. (1966). New Engl. F. Med., 275, 575.

Mims, C. A. (1964). Bact. Rev., 28, 30.

Partman, P. D., Buescher, E. L., and Artenstein, M. S. (1962). Proc. Soc. exp. Biol. (N.Y.), 111, 225.

Phillips, C. A., Melnick, J. L., Yow, M. D., Bayatpour, M., and Burkhardt, M. (1965). f. Amer. med. Ass., 193, 1027.

Plotkin, S. A., Dudgeon, J. A., and Ramsay, A. M. (1963). Brit. med. f., 2, 1296.

Plotkin, S. A., Klaus, R. M., and Whitely, J. P. (1966). F. Pediat., 69, 1085 .

Plotkin, S. A., et al. (1967). 7. Amer. med. Ass., 200, 435.

Rausen, A. R., Richter, P., Tallal, L., and Cooper, L. Z. (1967). f. Amer. med. Ass., 199, 75.

Schiff, G. M., Sever, J. L., and Huebner, R. J. (1965). Arch. intern. Med., 116, 537

Sever, J. L., and Monif, G. (1965). Amer. F. Dis. Child., 110, 452.

Sever, J. L., Schiff, G. M., and Traub, R. G. (1962). F. Amer. med. Ass., 182, 663.

Sever, J. L., et al. (1966). Proc. Soc. exp. Biol. (N.Y.), 122, 513.

Simons, M. J. (1969). Lancet. In press.

Simons, M. J., and Jack, I. (1968). Lancet, 2, 953.

Veronelli, J. A., Maassab, H. F., and Hennessy, A. V. (1962). Proc. Soc. exp. Biol. '(N.Y.), 111, 472 .

Weller, T. H., and Neva, F. A. (1962). Proc. Soc. exp. Biol. (N.Y.), 111, 215 .

Zinkham, W. H., Medearis, D. N., and Osborn, J. E. (1967). 7. Pediat., 71,512 